J. Japan. Soc. Hort. Sci. 55(4) : 498-509. 1987.

\title{
Astringency Removal and Ripening as Related to Temperature during the de-Astringency by Ethanol in Persimmon Fruits
}

\author{
Kiminori $\mathrm{KATO}^{2}$ \\ Fukushima Fruit Tree Experiment Station, Iizaka, \\ Fukushima 960-02
}

\begin{abstract}
Summary
The changes in fruit constituents and other characteristics of persimmon fruits treated with ethanol alone or ethanol plus ethylene were examined during deastringency and ripening at various temperatures ranging from $5^{\circ}$ to $40^{\circ} \mathrm{C}$.

1. There was a rapid decrease in tannin concentration at high temperatures with a 1.9-fold decrease for each $10^{\circ} \mathrm{C}$ rise in temperature.

2. A gradual decrease in flesh firmness occurred during the early holding period at $15^{\circ}$ to $40^{\circ} \mathrm{C}$. At $10^{\circ} \mathrm{C}$ the firmness decreased slowly and at a very slow or almost undetectable rate at $5^{\circ} \mathrm{C}$. Later, there was a rapid decrease in firmness, but no significant difference was found in the rate of decrease at temperatures of $5^{\circ}$ to $25^{\circ} \mathrm{C}$. At $10^{\circ} \mathrm{C}$, however, this rapid decrease in firmness began earlier than at $15^{\circ}$ to $30^{\circ} \mathrm{C}$ and the softening fruits appeared to become water-logged in the flesh region.

3. The decrease in peel chlorophyll concentration was rapid at $15^{\circ} \mathrm{C}$ and slow at both $5^{\circ}$ and $30^{\circ} \mathrm{C}$. The increase in peel carotenoid concentration was rapid as the temperature was increased from $5^{\circ}$ to $30^{\circ} \mathrm{C}$, and in this case no appreciable amount of lycopene was found in the peel.

4. The decrease in flesh firmness began earlier in ethylene-treated fruits than in untreated ones. The softening accelerated by ethylene treatment remained at a constant level during holding at any temperature thereafter.

5. The concentration of ethanol vapor within packed cartons rose quickly to a peak about 1 hour after the application of the ethanolic solution and then decreased rapidly. These changes were more apparent with higher temperatures. The penetration of applied ethanol into fruits was almost complete within less than 3 days even at a low temperature of $10^{\circ} \mathrm{C}$.
\end{abstract}

\section{Introduction}

A conventional method of de-astringency in persimmon fruits using ethanol has a disadvantage of requiring a long time for fruits to become non-astringent, because packed cartons were stored at ambient temperatures. To shorter the de-astringency period, an effective method is to hold fruits

1 Recieved for publication February 10, 1986.

Improvement on removing astringency in persimmon fruits by ethanol. III.

2 Present address: Fukushima Junior College of Agriculture, Iizaka, Fukushima 960-02 at higher temperatures during this period. However, the relationship between temperatures and de-astringency rates has not been reviewed in detail. In addition, there are very few reports about the relationship between temperatures and ripening rates, for cases where ripening takes place with a concomitant loss of astringency. Such basic information would be useful to the application of de-astringency methods over a short period. This study was therefore made to determine the relationship of holding temperatures to the rates of both de-astringency and ripening of fruits. 


\section{Materials and Methods}

Two varieties of astringent persimmon, 'Aizumishirazu' and 'Hiratanenashi' were harvested at a proper stage of maturity from the Experimental Orchard of Aizu and a local planting near the Fukushima Fruit Tree Experiment Station. Two experimental units were developed for treatment. One employed the same apparatus as in the previous report(5), where a continuous flow of air, and ethanol vapor and ethylene in air are metered through the chambers containing fruits. The other employed the conventional equipment, where fruits are packed in a carton holding $15 \mathrm{~kg}$ net weight (30 by $40 \mathrm{~cm}$ in depth by $21 \mathrm{~cm}$ ), and sealed after the application of an aqueous ethanolic solution. By using these units, 4 separate experiments were conducted.

\section{Experimental procedures}

Expt.1. 'Hiratanenashi' fruits harvested in 1975 were placed in glass chambers at $25^{\circ} \mathrm{C}$, and treated with ethanol for 1 day by supplying air which had been passed over a $25 \%$ ethanolic solution. After the ethanol treatment, chambers were opened and fruits were divided into 4 equal groups, which were then transferred to constant temperature rooms held at $15^{\circ}, 20^{\circ}, 30^{\circ}$ and $40^{\circ} \mathrm{C}$, respectively.

Expt.2. 'Aizumishirazu' fruits harvested in 1982 were treated with ethanol in the same manner as in Expt. 1, except that the holding temperature was $30^{\circ} \mathrm{C}$ and the concentration of ethanolic solution used was $10 \%$. Thereafter, the fruits were kept continuously in the chambers for 1 day and air alone or ethylene in air was introduced during this period. Using the method described by Pratt et al. (9), the concentration of ethylene was adjusted to be about $4 \mathrm{ppm}$ (3. 6 to $5.0 \mathrm{ppm}$ ). The chambers were opened after 2 days, and both ethylenetreated and untreated fruits were divided into 4 groups, which were then transferred to rooms held at $10^{\circ}, 15^{\circ}, 20^{\circ}$ and $30^{\circ} \mathrm{C}$.

Expt.3. 'Hiratanenashi' fruits harvested in 1983 were treated with ethanol alone and ethanol plus ethylene in the same manner as in Expt. 2, except that chambers were aerated for 1 day after the end of ethanol treatment and fruits were then exposed to $1.5 \mathrm{ppm}$ ethylene (1.0 to $1.9 \mathrm{ppm})$. After 3 days, the chambers were opened and the fruits were moved to the rooms held at $5^{\circ}$, $10^{\circ}, 15^{\circ}$ and $25^{\circ} \mathrm{C}$.

Expt.4. 'Hiratanenashi' fruits harvested in 1983 were packed in cartons which had no ventilation holes and were lined or unlined with polyethylene (poly-) bags (0.02 $\mathrm{mm}$ thick, 49 by $79 \mathrm{~cm}$ ). The cartons were placed uncovered in constant temperature

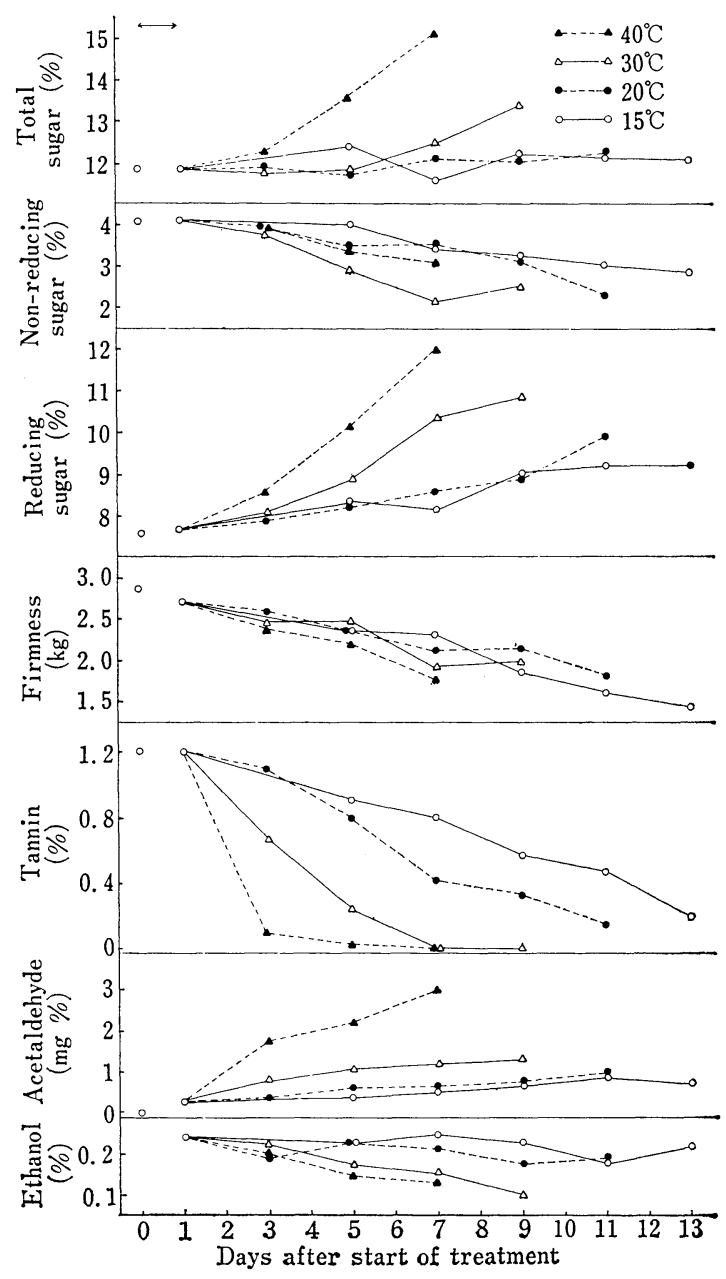

Fig. 1. Changes in physicochemical properties of Hiratanenashi fruits treated with ethanol at $20^{\circ} \mathrm{C}$ for 1 day and then held at $15^{\circ}, 20^{\circ}$, $30^{\circ}$ and $40^{\circ} \mathrm{C}$. The horizontal line in the upper portion of figure indicates the duration of treatment. 


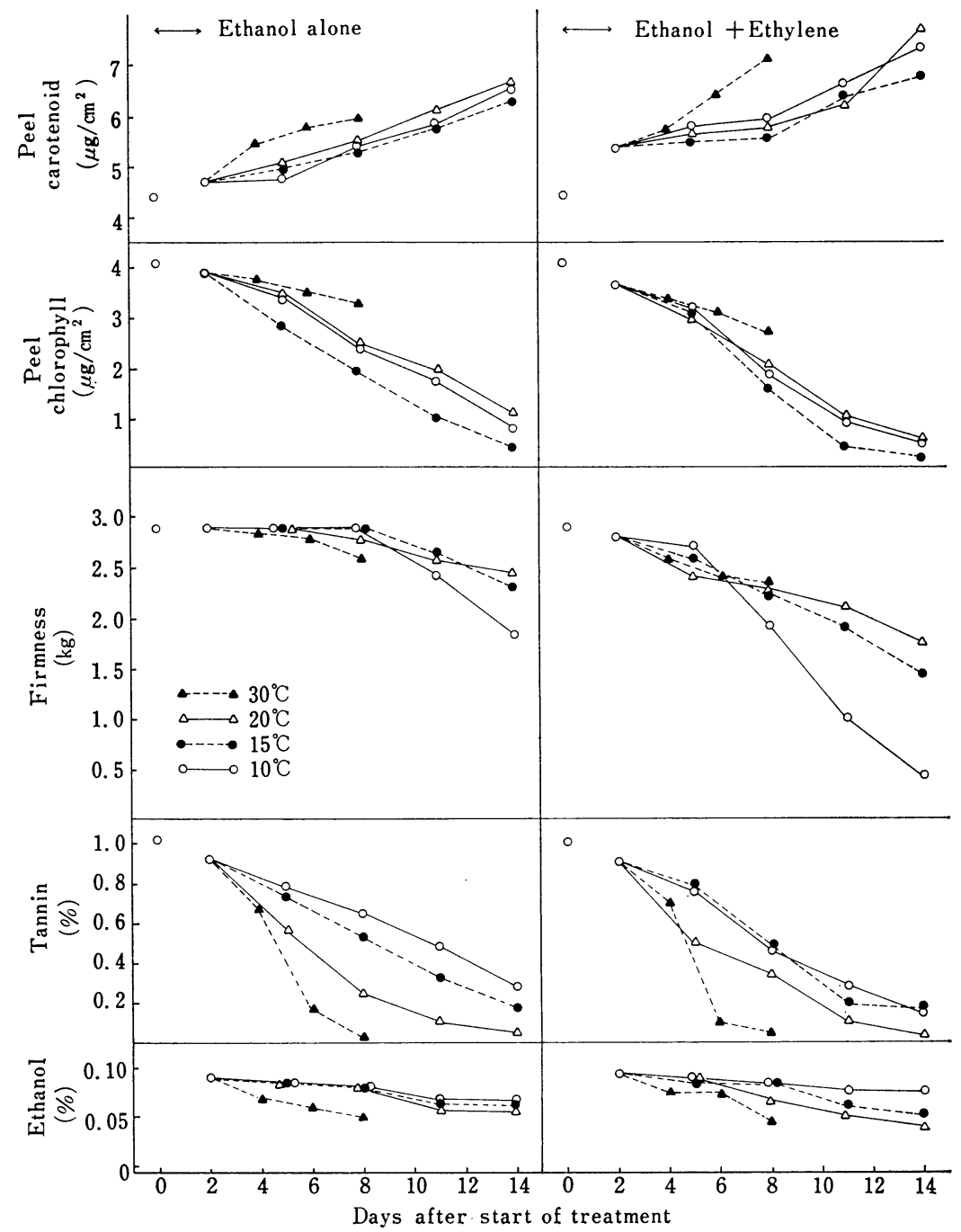

Fig. 2. Changes in physicochemical properties of Aizumishirazu fruits treated with ethanol alone and ethanol plus ethylene at $30^{\circ} \mathrm{C}$ for 2 days and then held at $10^{\circ}, 15^{\circ}, 20^{\circ}$ and $30^{\circ} \mathrm{C}$. The duration of treatment is indicated by the same manner as in Fig.1.

rooms held at $10^{\circ}, 15^{\circ}$ and $25^{\circ} \mathrm{C}$ and after 6 hours, when fruit temperatures attained approximate equilibrium with room temperatures, a $35 \%$ ethanolic solution was applied. The rates of spray application per $1 \mathrm{~kg}$ of fruit were 4 and $15 \mathrm{ml}$ with and without polybags, respectively. The carton was immediately sealed by covering the fruits either with the end of the polybag folded or with a few sheets of newspaper.

2. Determinations of de-astringency and

\section{ripening characteristics}

The following parameters were determined periodically before and after transfer to each constant temperature room : ethanol and tannin in the flesh and flesh firmness in each experiment; sugars in the flesh in Expt.1; acetaldehyde in the flesh in Expt. 1 and 4 ; carbon dioxide and ethylene evolution of fruits in Expt. 2 ; chlorophyll and carotenoid in the peel in Expt. 2, 3 and 4 ; fruit color score in Expt. 3 and 4 ; carbon dioxide, oxy- 


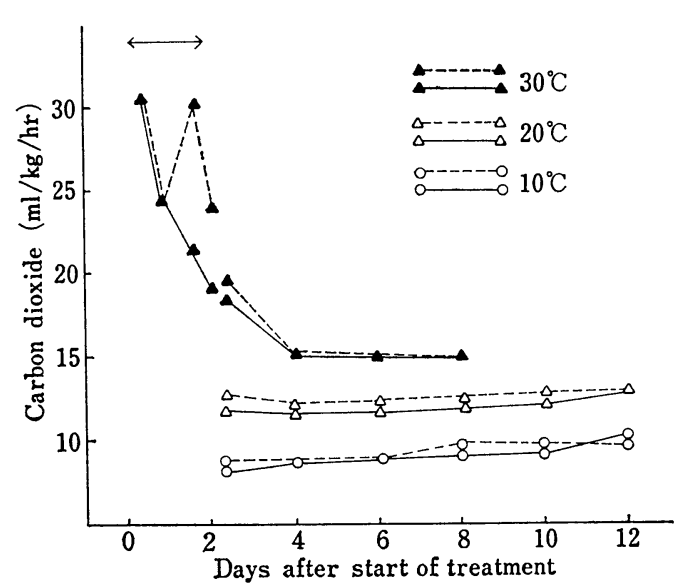

Fig. 3. Changes in carbon dioxide evolution of Aizumishirazu fruits treated with ethanol alone (solid line) and ethanol plus ethylene (dotted line) at $30^{\circ} \mathrm{C}$ for 2 days and then held at $10^{\circ}, 20^{\circ}$ and $30^{\circ} \mathrm{C}$. The duration of treatment is indicated by the same manner as in Fig. 1.

gen, ethylene and ethanol vapor within cartons in Expt.4. The fruit color score was evaluated by a visual rating of surface color in the most highly colored and green sides of fruits. The other determinations were made by the same methods as reported previously $(5,6)$.

\section{Results}

Expt. 1. The effect of temperature on 'Hiratanenashi' fruits treated with ethanol is shown in Fig. 1. The concentration of ethanol reached $0.24 \%$ after 1 day and then decreased gradually. The rate of decrease was high with higher temperatures. The acetaldehyde concentration increased gradually with a large increase in rate at $40^{\circ} \mathrm{C}$. The decrease in tannin concentration started after 1 day and by reference to the curves in the figure, the times required to reach about $0.2 \%$ were $12,9.5,4$ and 2 days at $15^{\circ}$, $20^{\circ}, 30^{\circ}$ and $40^{\circ} \mathrm{C}$, respectively. The time difference was about one-half for each $10^{\circ} \mathrm{C}$ rise in temperature. A gradual decrease in flesh firmness began after 1 day, and there were no significant differences in the rate among the various holding temperatures ranging from $15^{\circ}$ to $40^{\circ} \mathrm{C}$. As the time elapsed, the concentration of reducing sugars gradually increased, while that of nonreducing sugars decreased. At temperatures of $30^{\circ}$ and $40^{\circ} \mathrm{C}$, these changes were more rapid and the concentration of total sugars increased due to an increase in reducing sugars exceeding a decrease in non-reducing sugars. At $40^{\circ} \mathrm{C}$ the increase in total sugars reached about $3 \%$ after 6 days.

Expt.2. Fig. 2 shows the effect of temperature on 'Aizumishirazu' fruits treated with ethanol alone and ethanol plus ethylene. The ethanol concentration was $0.09 \%$ after 2 days, and then decreased gradually. A decrease in tannin concentration began after 2 days with a high rate of decrease with high temperatures. Above $15^{\circ} \mathrm{C}$ gradual decreases in flesh firmness began after about 5 to 8 days in fruits treated with ethanol alone and after 2 days in those with ethanol plus ethylene, and no significant differences were found in the rate of decrease. At $10^{\circ} \mathrm{C}$, however, more rapid decreases in firmness began after 8 days in fruits treated with ethanol alone and after 5 days in those with ethanol plus ethylene. Moreover, the fruits softening at $10^{\circ} \mathrm{C}$, whether treated with ethanol alone or with ethanol plus ethylene, became water-logged in the flesh region but this was not observed at the other temperatures. The concentration of peel chlorophyll decreased with time and decreased fastest at $15^{\circ} \mathrm{C}$, followed in order by $10^{\circ}$, $20^{\circ}$ and $30^{\circ} \mathrm{C}$. The concentration of peel carotenoid increased with time with the increase being greatest at $30^{\circ} \mathrm{C}$.

Fig. 3 shows the carbon dioxide evolution rates of fruit at various temperatures. The rates decreased rapidly during the first 2-day period in fruits treated with ethanol alone, but in fruits treated with ethanol plus ethylene a temporary rise in rate occurred during exposure to ethylene. After transfer to each temperature, the evolution rates levelled off to a fairly constant level at each temperature and no significant difference was found between fruits treated with ethanol alone and those with ethanol plus ethylene. Although data are not presented here, it was found that the rates of ethylene evolution were about $0.02 \mu \mathrm{l} / \mathrm{kg} \cdot \mathrm{hr}$ or less and therefore too 


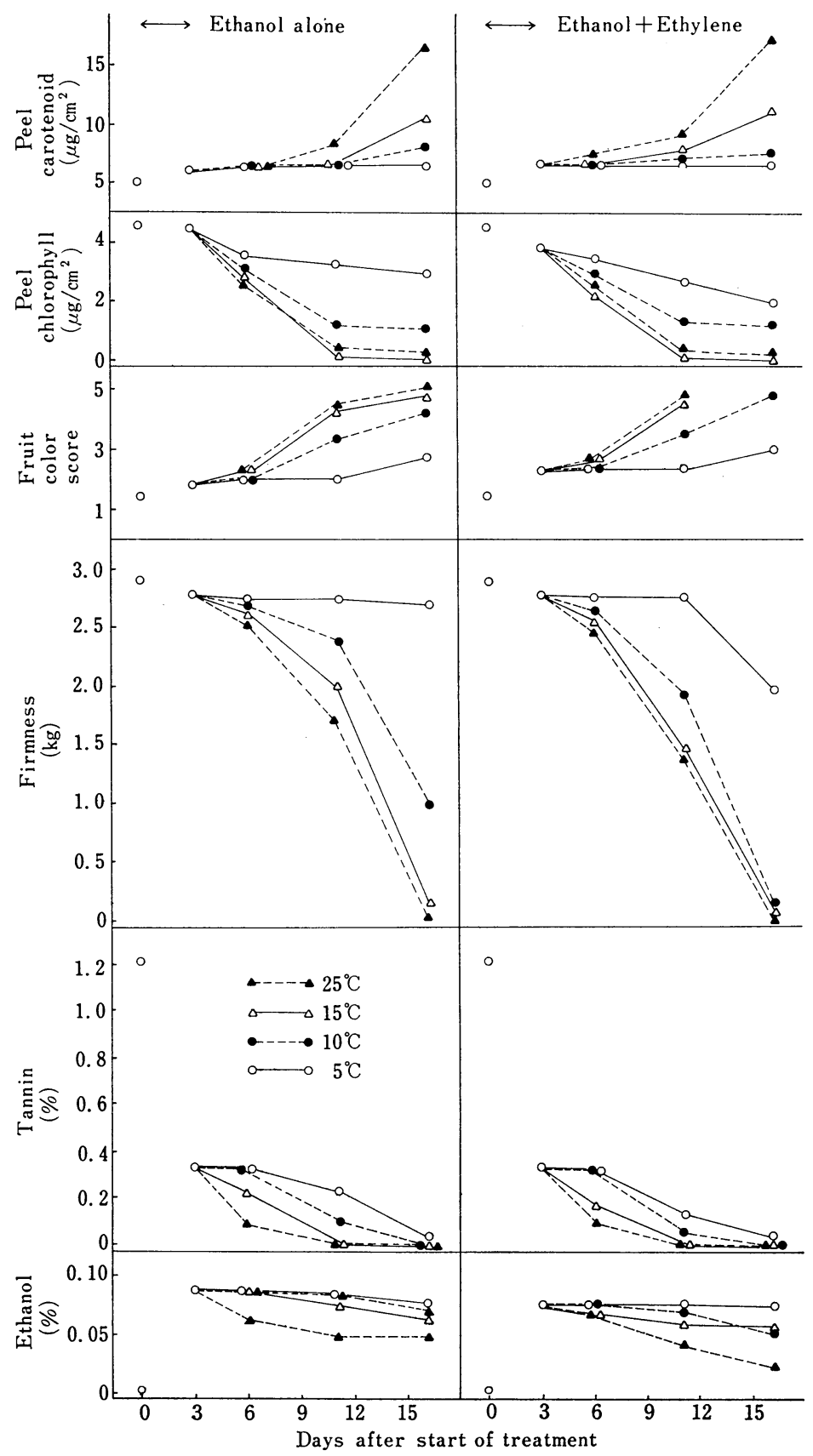

Fig. 4. Changes in physicochemical properties of Hiratanenashi fruits treated with ethanol alone and ethanol plus ethylene at $30^{\circ} \mathrm{C}$ for 3 days and then held at $5^{\circ}, 10^{\circ}, 15^{\circ}$ and $25^{\circ} \mathrm{C}$. The duration of treatment is indicated in the same manner as in Fig. 1.

low for the differences to be detected among holding temperatures or test dates.

Expt.3. The effect of temperature on
'Hiratanenashi' fruits treated with ethanol alone and ethanol plus ethylene is shown in Fig. 4. The ethanol concentration was 


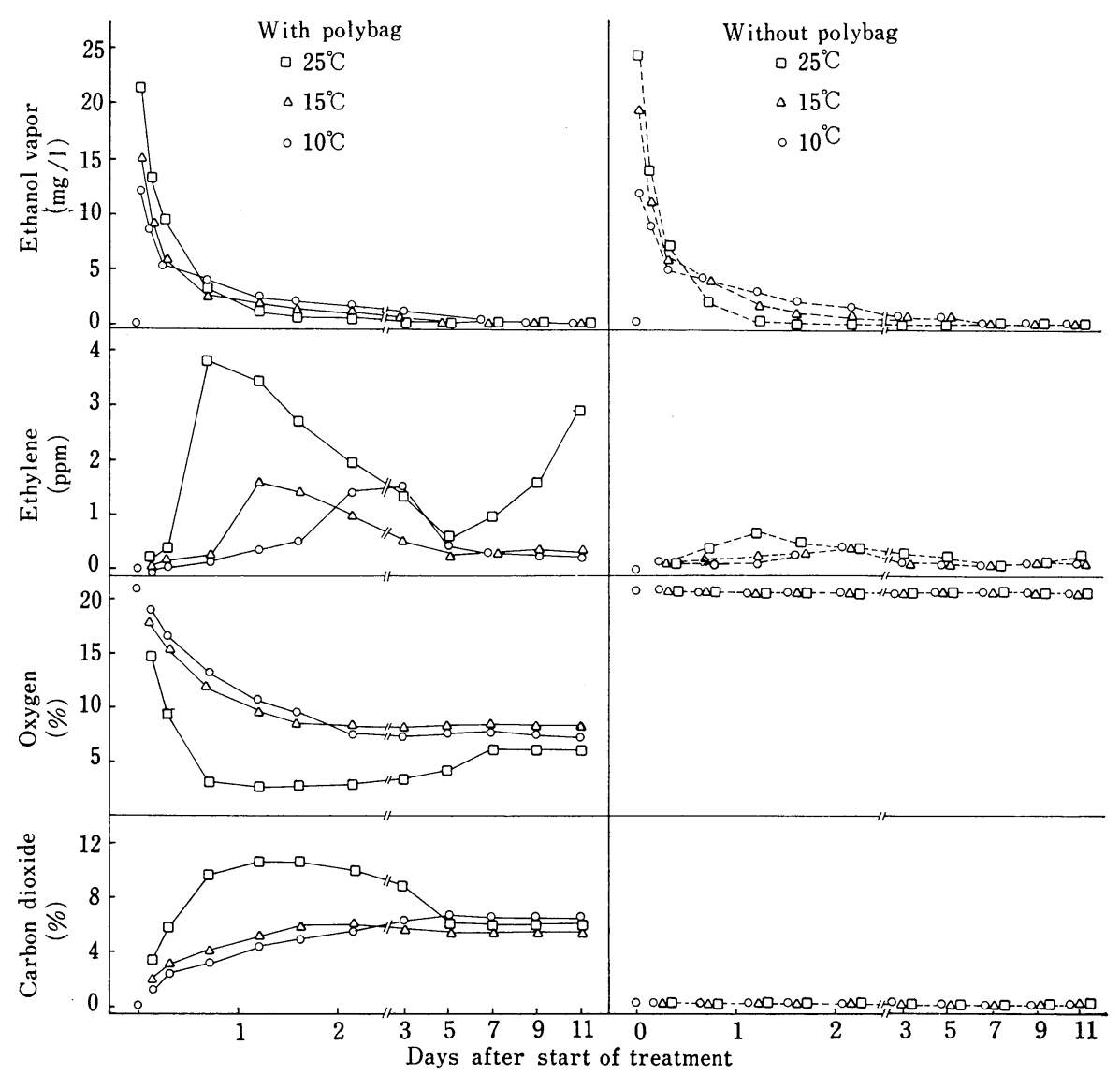

Fig. 5. Changes in gas concentrations within packed cartons of Hiratanenashi fruits packaged with and without polybags. Packaged fruits were held at $10^{\circ}, 15^{\circ}$ and $25^{\circ} \mathrm{C}$ and then applied with an aqueous ethanolic solution.

about $0.08 \%$ immediately after treatment, and then decreased rapidly with high temperatures. The tannin concentration was about $0.3 \%$ after 3 days and then decreased rapidly with high temperatures, resulting in that the number of days required to attain $0.1 \%$ was reduced by about one-half for each $10^{\circ} \mathrm{C}$ rise in temperature. The flesh firmness at $5^{\circ} \mathrm{C}$ did not change significantly for 16 days in fruits treated with ethanol alone and for 11 days in those with ethanol plus ethylene. Above $10^{\circ} \mathrm{C}$ firmness decreased rapidly except in fruits treated with ethanol alone at $10^{\circ} \mathrm{C}$, which showed a somewhat slower decrease. The increase of fruit color score was very slow at $5^{\circ} \mathrm{C}$ but rapid above $15^{\circ} \mathrm{C}$. This increase was earlier in fruits treated with ethanol plus ethylene than in those with ethanol alone. The decrease of peel chlorophyll concentration was very slow at $5^{\circ} \mathrm{C}$ but rapid at $15^{\circ} \mathrm{C}$. The increase of peel carotenoid concentration was negligihle at $5^{\circ} \mathrm{C}$ but rapid at $25^{\circ} \mathrm{C}$.

Expt.4. The effect of temperature on 'Hiratanenashi' fruits packed in cartons was determined. As shown in Fig. 5, carbon dioxide in cartons with polybags after 1 to 2 days increased to about $6 \%$ at $10^{\circ}$ to $15^{\circ} \mathrm{C}$ and to about $10 \%$ at $25^{\circ} \mathrm{C}$. After 5 days the concentration remained at a constant level of about $6 \%$ at any temperature. Carbon dioxide in cartons without polybags was hardly accumulated. Oxygen in cartons with polybags declined to about $2 \%$ at $25^{\circ} \mathrm{C}$ after 1 day and to about $8 \%$ at $10^{\circ}$ to $15^{\circ} \mathrm{C}$ after 2 days, but from 7 days it stabilized 


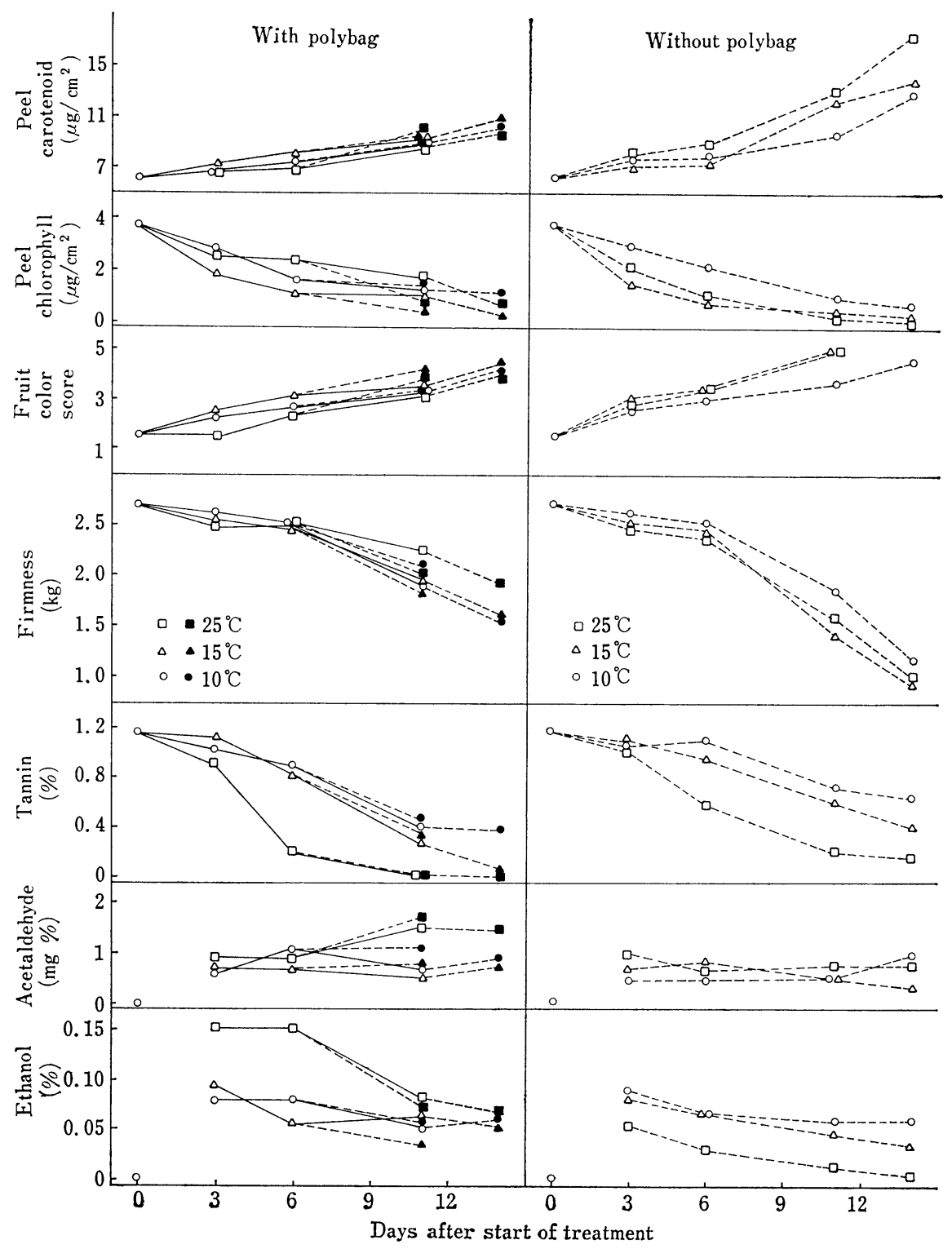

Fig. 6. Changes in physicochemical properties of Hiratanenashi fruits packed in cartons with and without polybags, held at $10^{\circ}, 15^{\circ}$ and $25^{\circ} \mathrm{C}$, and then treated with an aqueous ethanolic solution. The solid and dotted lines for cartons with polybags indicate the changes before and after opening the polybags, respectively.

at about 6 to $8 \%$ at any temperature. Oxygen in cartons without polybags held near $20 \%$. Ethylene after 1 day at $25^{\circ} \mathrm{C}$ increased to about 4 and $0.7 \mathrm{ppm}$ in cartons with and without polybags, then declined gradually. In cartons with polybags, however, there was a gradual increase starting after 5 days. At $10^{\circ}$ to $15^{\circ} \mathrm{C}$, ethylene after 1 to 2 days increased to about 1.5 and $0.5 \mathrm{ppm}$ in cartons with and without polybags, then declined gradually. The concentration of ethanol vapor rose quickly to a peak of $10 \mathrm{mg} / \mathrm{l}$ or more about 1 hour after the application of ethanolic solution, and declined rapidly for 1 to 2 days, followed by a gradual decline. These changes did not differ significantly between cartons with polybags and those without polybags. 
Table 1. The discoloration scores of peel surface at 11 days after the application of aqueous ethanolic solution as affected by holding temperature, packing position within cartons and type of packaging.

\begin{tabular}{clcc}
\hline \hline \multirow{2}{*}{$\begin{array}{c}\text { Holding } \\
\text { temp. }\end{array}$} & $\begin{array}{l}\text { Packing } \\
\text { position }\end{array}$ & \multicolumn{2}{c}{ Discoloration score ${ }^{z}$} \\
\cline { 3 - 4 } & With polybag & Without polybag \\
\hline \multirow{2}{*}{$10^{\circ} \mathrm{C}$} & Top & 1.9 & 1.4 \\
& Middle & 1.6 & 1.5 \\
& Bottom & 2.4 & 2.1 \\
$200^{\circ} \mathrm{C}$ & Top & 1.4 & 1.3 \\
& Middle & 1.5 & 1.9 \\
& Bottom & 2.5 & 2.3 \\
$25^{\circ} \mathrm{C}$ & Top & 1.5 & 1.1 \\
& Middle & 1.5 & 1.3 \\
& Bottom & 1.8 & 1.7 \\
\hline
\end{tabular}

z Discoloration score : $1=$ none to slight, $2=$ moderate, $3=$ severe

The ethanol concentration, as shown in Fig. 6, seemed to be the highest on the 3rd day of the 1st test date and to decline gradually thereafter. At $10^{\circ}$ and $15^{\circ} \mathrm{C}$ the ethanol concentrations were about $0.09 \%$ in fruits packaged either with or without polybags, but at $25^{\circ} \mathrm{C}$ they were 0.15 and $0.05 \%$ in fruits packaged with and without polybags, respectively. The acetaldehyde concentration increased to around $0.7 \mathrm{mg} \%$ in 3 days, and then levelled off at an almost constant level except in fruits packaged with polybags at $25^{\circ} \mathrm{C}$, which showed a continued increase to about $1.5 \mathrm{mg} \%$. The tannin concentration decreased with time, and judging from the curves in the figure, the times required to reach about $0.4 \%$ at $10^{\circ}, 15^{\circ}$ and $25^{\circ} \mathrm{C}$ were about 11,10 and 5 days in fruits packaged with polybags and more than 14, 14 and 8 days in unpackaged fruits. In fruits packaged with polybags, no significant differences were found in the tannin concentrations after 11 days whether the polybags were opened after 6 days or after 11 days. In fruits packaged with polybags the changes in flesh firmness, fruit color score, peel chlorophyll and carotenoid concentrations were slower at $25^{\circ} \mathrm{C}$ than at the other temperatures, while in unpacked fruits they were slower at $10^{\circ} \mathrm{C}$. Changes occurred slower in fruits packaged with polybags than in unpackaged fruits, but after opening the polybags no significant differences were observed.

Some of fruits packed in cartons developed brown stains on the peel from apex to median with similar symptoms apparent in all treatment. As seen in Table 1, more discoloration of fruits occurred at $10^{\circ}$ and $15^{\circ} \mathrm{C}$ than at $25^{\circ} \mathrm{C}$. Discoloration was greater in the bottom layer than in the middle and top layers within a carton and greater with polybags than without them. Further, moisture within a carton was determined to find its relationship to the development of peel discoloration. A sheet of corrugated cardboard beneath fruits packaged either with or without polybags was almost dry at $25^{\circ} \mathrm{C}$, while it was wet at $10^{\circ}$ and $15^{\circ} \mathrm{C}$. At $10^{\circ} \mathrm{C}$ water was noticeable if the wet cardboard was pressed with the fingers.

\section{Discussion}

\section{The decrease in tannin concentration}

The time required for the tannin concentration to reach a given level after transfer to each constant temperature room showed a 2 -fold decrease for every $10^{\circ} \mathrm{C}$ rise in temperature. This relationship will be expressed by the following equation: $\mathrm{D}_{1} / \mathrm{D}_{2}=\mathrm{Q}_{10}{ }^{\left(t_{2}-t_{1}\right) / 10}$ where $D_{1}$ or $D_{2}=$ number of days required for de-astringency at an experienced temperature of $t_{1}$ or $t_{2} ; Q_{10}=$ the increase of deastringency rate for every $10^{\circ} \mathrm{C}$ rise in temperature. In Fig. $1, D_{1}$ gave 12 days at $t_{1}$ of $15^{\circ} \mathrm{C}$ and $\mathrm{D}_{2}$ gave 4 days at $t_{2}$ of $30^{\circ} \mathrm{C}$, and in this case $Q_{10}$ was given a value of 2.1 by using the above equation. When the same calculations were made using the data obtained from the curves in Fig. 1, 2 and 4, $\mathrm{Q}_{10}$ gave values ranging from 1.4 to 2.4 with an average of 1.9. Though there were significant differences in the tannin concentrations immediately after transfer to various temperatures, the value of $Q_{10}$ was almost constant. This probably indicates that the de-astringency rate depends directly on the holding temperature regardless of the degree of astringency removed. Another indication is that the coagulations of individual tannin cells during the de-astringency occur in succession but independently of one another. 
There was an increase in acetaldehyde concentration at high temperatures, but this relationship was not so obvious as that of the change in tannin concentration to holding temperature. Although acetaldehyde concentrations greatly influence the de-astringency rate( 7$)$, the above fact shows that large decreases in the tannin concentration at high temperatures can not be explained only by the increase in acetaldehyde concentration. On the other hand, the responses to treatment with various temperatures are similar in the carbon dioxide evolution and the de-astringency rates. It seems likely that as with the carbon dioxide evolution rate or the respiratory activity, the deastringency process involves overall physiological and biochemical reactions within a tannin cell.

\section{The decrease in flesh firmness}

There were various patterns in the decrease of flesh firmness during holding at various temperatures, i.e. a gradual decrease from the initial level to that of 1.5 to $2.0 \mathrm{~kg}$ as shown in Fig. 1 ; no or little decrease during the early period and then a gradual or rapid one as shown in Fig. 2 ; and a gradual decrease during the early period followed by a rapid decrease as shown in Fig. 4 . If the difference in these 3 patterns is considered to be due to the different maturities of fruits used, the 2nd pattern indicates the earliest stage of maturity, followed in order by the 1 st and the 3 rd ones. Iwata et al. (3) reported that persimmon fruits remained fairly firm for a long time after harvest, but then softened rapidly. During this experiment, it is considered probable that only a part of the entire pattern of decrease in firmness is observed during the relatively short period of about 2 weeks.

It is assumed that the period during no or a gradual decrease in firmness is due to the time needed to prepare physiological conditions in the tissue necessary for the subsequent rapid changes. As a rapid decrease in firmness occurred earlier in ethylene-treated fruits than in untreated ones, ethylene may have some function in the formation of such physiological conditions.
In Expt. 2, however, no detectable increase in ethylene evolution was found at $10^{\circ} \mathrm{C}$ despite the occurrence of a rapid decrease in firmness. Maotani et al. (8) reported that ethylene is the most important factor in the softening of persimmon fruits, and their report shows that less than $1 \mathrm{ppm}$ of ethylene is obviously efficient. These facts may indicate that the onset of a rapid decrease in firmness is complexly connected with factors such as a slight increase in ethylene production below the threshold of detection, and the accelerated sensitivity of fruits to ethylene in relation to holding temperature and/or maturity of fruits.

A rapid decrease in firmness occurred earlier at $10^{\circ} \mathrm{C}$ than at the other temperatures. A similar result was obtained by Chujo and Ashizawa(2), and they reported that the fruits harvested late in the season tended to soften rapidly at $10^{\circ} \mathrm{C}$. Moreover, the fruits softening at $10^{\circ} \mathrm{C}$ developed waterlogged tissue in Expt.2, and this tendency was also observed in Expt. 3. It may be possible that holding at $10^{\circ} \mathrm{C}$ induces a specific physiological process within the fruit, but further work will be required to explain this process.

\section{Changes in fruit color and peel pig-} ments

The decrease in peel chlorophyll concentration was most rapid at around $15^{\circ} \mathrm{C}$, while the increase in peel carotenoid concentration was rapid at a higher temperature of $30^{\circ} \mathrm{C}$. The fruits held at around $30^{\circ} \mathrm{C}$, therefore, tended to attain an orange color of high intensity with a relatively slow loss of green color as compared with those held at around $15^{\circ} \mathrm{C}$. As poorly colored fruits, even those slightly green at the stem end, do not bring a high market price, the rapid loss of peel chlorophyll is important. Fruits treated to remove astringency at around $30^{\circ} \mathrm{C}$ are also required to be well colored.

When the peel carotenoids of well colored fruits were extracted with petroleum ether and the absorption curve between 400 and $550 \mathrm{~nm}$ was determined, the solution had a very low absorption at about $500 \mathrm{~nm}$ with a peak at about $450 \mathrm{~nm}$. This result may 
indicate that none or only a small amount of lycopene is contained in the peel(1).

Hence, it must be conceded that the increase in peel carotenoid concentration is greater at $30^{\circ} \mathrm{C}$.

\section{The behavior of applied ethanol}

The concentration of ethanol vapor within cartons declined rapidly from about 1 hour after the application of ethanolic solution, resulting in a very low level after 3 days. The ethanol concentration in the flesh seemed to be highest after 3 days even at $10^{\circ} \mathrm{C}$. It therefore seems probable that the penetration of ethanol into fruits is almost complete within 3 days after application.

Fruits packaged either with or without polybags at $10^{\circ}$ and $15^{\circ} \mathrm{C}$ contained about $0.09 \%$ of ethanol in the flesh. From the concentration and quantity of ethanolic solution used, the amount of ethanol applied initially was computed to be 0.11 and $0.40 \mathrm{~g}$ per $100 \mathrm{~g}$ of fruits packaged with and without polybags, respectively. So about $80 \%$ of the applied ethanol penetrated into the fruits packaged with polybags and $20 \%$ into the fruits without polybags. However, the fruits packaged with polybags at $25^{\circ} \mathrm{C}$ contained $0.15 \%$ of ethanol in the flesh, which was higher than the calculated amount of applied ethanol. This is thought to be due to unaerobic respiration taking place under the atmosphere of low oxygen and elevated carbon dioxide concentration present within the polybags.

The ethanol concentration in the flesh decreased gradually after transfer to each temperature with the rate of decrease being higher at higher temperatures (Fig. 1, 2 and 4). In contrast with the penetration of ethanol into fruits, ethanol vapor seemed to be evolved by fruits. The concentration of ethanol vapor in equilibrium with a given concentration of ethanolic solution increased 2 -fold for each $10^{\circ} \mathrm{C}$ rise in temperature(5), which supports the above observation.

5. Eating quality as related to holding temperature

Fruits becoming non-astringent in 10 days or more at $15^{\circ}$ to $20^{\circ} \mathrm{C}$ were sweet, jellylike, but still firm with a splendid texture. How- ever, flesh texture tended to be less acceptable at higher temperatures, and the fruits held at $40^{\circ} \mathrm{C}$ were poor in quality because of their non-melting texture even when sof tened to the most desirable firmness values of around $2 \mathrm{~kg}$ (Expt. 1). In view of these points, it may be concluded that the holding temperature to develop better eating quality is $15^{\circ}$ to $20^{\circ} \mathrm{C}$ with a possible maximum temperature of about $30^{\circ} \mathrm{C}$. In general, the ripening temperature recommended for attaining the highest quality is known to be around $20^{\circ} \mathrm{C}$ in deciduous fruits such as pear and peach, and if these fruits are ripened above about $30^{\circ} \mathrm{C}$ their eating quality will be poor. This fact is probably true with persimmon fruits.

The fruits treated with ethanol at $30^{\circ} \mathrm{C}$ remained hard and crisp at firmness values of $2.5 \mathrm{~kg}$ or higher for a relatively long time after they became non-astringent. These fruits will not be suited for marketing because of the lack of sweetness and juicyness. A similar view has been proposed by Kaneko et al. (4). In this case, the ethylene treatment, which hastens the softening and ripening of fruits, seems to be useful. Moreover, the difference in softening rate between ethylene-treated fruits and untreated ones did not vary significantly during holding at any temperature after the ethylene treatment. This result suggests that there is another advantage in that ethylene-treated fruits have a greater shelf life than ordinary fruits if their softening is speeded up correctly.

\section{Acknowledgement}

The author is grateful to the management of the Fukushima Fruit Tree Experiment Station where this work was done and to Miss Y.Ono for her assistance during this experiment.

\section{Literature Cited}

1. Chujo, T. 1971. Studies on the coloration in the fruits of Fuyu Kaki. II. Effect of light intensity on the development of reddish color of the peel. Tech. Bull. Fac. Kagawa Univ. $23: 35-41$. (In Japanese with English summary) 
2. Chujo, T. and M. Ashizawa. 1973. Studies on the coloration in the fruits of Fuyu Kaki. III. Effect of temperatures on the development of reddish color of the peel of detached Kaki fruits. Tech. Bull. Fac. Agr. Kagawa Univ. 24:129-135. (In Japanese with English summary)

3. IWATA, T., K. NakAgawa and K. Ogata. 1969. Relationship between the ripening of harvested fruits and the respiratory pattern. On the class of respiratory pattern of Japanese persimmons. J. Japan. Soc. Hort. Sci. $38: 194-201$. (In Japanese with English summary)

4. KANEKo, K., T. AKIYA and C. ARAKI. 1974. Studies on removal of astringency in persimmons. II. The use of zeolite for ethanol spray and temperature effects on astringency removal. Abstr. Japan. Soc. Hort. Sci. Autumn Meet. 1974. 382-383. (In Japanese)

5. KATO, K. 1984. The condition of tannin and sugar extraction, the relation of tannin concentration to astringency and the behaviour of ethanol during the de-astringency by ethanol in persimmon fruits. J. Japan. Soc. Hort. Sci. 53:127-134. (In Japanese with
English summary)

6. KATO, K. 1984. Astringency removal and ripening as related to ethanol concentration during the de-astringency by ethanol in persimmon fruits. J. Japan. Soc. Hort.

Sci. 53:278-289. (In Japanese with English summary)

7. Kitagawa, H. 1969. Studies on the removal of the astringency and storage of Kaki (Oriental persimmon). V. A relation between removal of the astringency and acetaldehyde formation during the warm water treatment for removal of the astringency. J. Japan. Soc. Hort. Sci. $37: 379-382$. (In Japanese with English summary)

8. MaOTANi, T., M. YamadA, A. KURIHARA, T. AKIMOTO and Y. IIYA. 1982. Storage of Japanese persimmon of pollination constant nonastringent type in polyethylene bags with ethylene absorbent. J. Japan. Soc. Hort. Sci. $51:$ 195-202. (In Japanese with English summary)

9. PRATT, H. K., M. WORKMAN, F. W. MARTIN and J. M. LYONS. 1960. Simple method for continuous treatment of plant material with metered traces of ethylene or other gases. Plant Physiol. 35 : 609-611. 
カキ果実のアルコール脱渋時における温度と脱橴及び追熟との関係

\author{
加藤公道 ${ }^{1}$ \\ 福島県果樹試験場 960-02 福島市飯坂町
}

\begin{abstract}
摘
エタノールのみまたはエチレンと併用して処理したカ キ果実を $5 \sim 40^{\circ} \mathrm{C}$ の異なる温度の恒温室内に置き, 脱渋 及び追熟期間中の果実形質その他の変化を調查した.

果実のタンニン含量の減少は高温下汪ぞ速く, その速 度は温度が $10^{\circ} \mathrm{C}$ 上昇すると約 1.9 倍になった。

果肉の硬度は, 最初は緩やかに低下し, その速度は 15

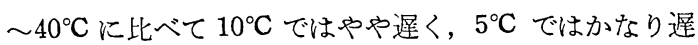
くて注とんど認められないほどであったが，その後は急

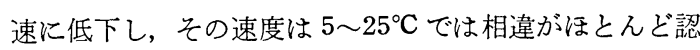

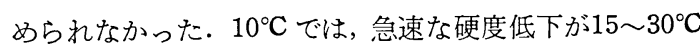
より早く始まり, 軟化した果肉は水浸状を示す傾向が認 められた。

果皮のクロロフィル含量の減少は $15^{\circ} \mathrm{C}$ 付近で速く, 低温の $5^{\circ} \mathrm{C}$ と高温の $30^{\circ} \mathrm{C}$ ではともに遅かった。一方, カロチノイド含量の増加は, $5 \sim 30^{\circ} \mathrm{C}$ では高温下ほど速
\end{abstract}

\section{要}

かった、なお，果皮にはリコピンがほとんど含まれてい なかった。

硬度低下は土チレン処理果の方が無処理果より早かっ た.エチレン処理により促進された硬度低下の促進程度 は，その後いずれの温度下に移しても，ほとんど变わら ずほぼー定で経過した。

ダンボール箱内のエタノールガス濃度は，アルコール 溶液を散布した後急上昇して約 1 時間後にピークに達 し，その後急速に低下した。この变化は，高温下ほどい くらか速かった．散布したエタノールのほとんどは，低 温の $10^{\circ} \mathrm{C}$ でも 3 日以内に果実内深透すると推定され た.

\footnotetext{
1 現在 福島県農業短期大学校
} 